\title{
OVERVIEW OF THE FITNESS PARAMETERS IN THE STUDENTS OF PÉCS UNIVERSITY
}

\section{PRZEGLĄD PARAMETRÓW SPRAWNOŚCIOWYCH WŚRÓD STUDENTÓW UNIWERSYTETU W PECZU}

\author{
Pongrác Ács $^{1(\mathrm{~A}, \mathrm{C})}$, Csaba Melczer $^{1(\mathrm{~B}, \mathrm{E}, \mathrm{F})}$, Tünde Sávolt-Szabó ${ }^{2(\mathrm{~B}, \mathrm{E})}$, Zsanett Welker $^{1(\mathrm{~B}, \mathrm{E})}$, \\ Monika Gyúróo ${ }^{1(\mathrm{E}, \mathrm{F})}$, Petra Baumann ${ }^{3(\mathrm{D}, \mathrm{F})}$, Kata Sey-Morvay ${ }^{1(\mathrm{~B}, \mathrm{~F})}$, Bence Raposa $^{1(\mathrm{C}, \mathrm{E}, \mathrm{F})}$
}

${ }^{1}$ Faculty of Health Sciences, University of Pécs, Pécs, Hungary

${ }^{2}$ University of Physical Education, Budapest, Hungary

${ }^{3}$ Medical School, University of Pécs, Hungary

Authors' contribution Wkład autorów:

A. Study design/planning zaplanowanie badań B. Data collection/entry zebranie danych

C. Data analysis/statistics dane - analiza i statystyki D. Data interpretation interpretacja danych E. Preparation of manuscript przygotowanie artykułu F. Literature analysis/search wyszukiwanie i analiza literatury G. Funds collection zebranie funduszy
Tables: 0

Figures: 6

References: 24

Submitted: 2017 Nov 30

Accepted: 2017 Apr 21

\section{Summary}

Background. Obesity and a sedentary way of life play an important part in public health in Hungary. This phenomenon is becoming more and more serious not only in adults but also children. Adults' health behaviour is greatly affected by the existence or absence of health awareness. Regular exercising in association with general fitness form an integral part of health awareness. Our objective is to demonstrate the nutrition and fitness status of students in higher education with a comprehensive test.

Material and methods. Beside general factors affecting health, such as BMI, skeletal muscle, body fat, visceral fat percentage, participants performed practical tasks which provided data of their stamina, muscular strength and fitness status: (1) a 15/20-minute shuttle run, (2) a scheduled abdominal muscle test (3) manual clamping force measurement (4) a scheduled push up test (5) a standing long-jump test, and (6) a flexibility test.

Results. According to our survey, young adults' nutrition status was satisfactory, two third of them had normal BMI. Left manual clamping force and trunk stretching force in men, stamina and explosive power in women were significantly determined by BMI classification. Basing on these results, we can state that body weight has no effect on joint mobility.

Conclusions. The present study draws attention to several former conclusions which suggest that more efforts are needed in higher education to improve health promotion of the youth. Introduction of compulsory physical education classes might facilitate further research which may follow-up the changes in the fitness status of young people.

Keywords: physical fitness, physical endurance, students, physical activity, motor skills

\section{Streszczenie}

Wprowadzenie. Otyłość i siedzący tryb życia stanowia ważna aspekt zdrowia publicznego na Węgrzech. Zjawisko to staje się coraz poważniejszym problemem nie tylko wśród dorosłych, ale i wśród dzieci. W istotnym stopniu wpływa na to zachowanie zdrowotne osób dorosłych, które charakteryzuje niska świadomość zdrowotna. Regularne ćwiczenia w połaczeniu z ogólnymi formami fitness stanowią integralną część świadomości zdrowotnej. Naszym celem jest wykazanie stanu odżywienia i sprawności studentów szkół wyższych poprzez kompleksowy system testowy.

Materiał i metody. Oprócz ogólnych czynników wpływających na zdrowie, takich jak BMI, mięśnie szkieletowe, tkanki tłuszczowej, tkanki tłuszczowej, uczestnicy wykonali zadania, które dostarczyły danych o ich wytrzymałości, sile mięśni, stanie sprawności: (1) 15/20-minutowy bieg (2) test mięśni brzucha (3) ręczny pomiar siły nacisku (4) test naciskowy (5) test długiego skoku (6) test elastyczności.

Wyniki. Naszym zdaniem, poziom odżywiania młodych ludzi był zadowalający, dwie trzecie z nich miało normalne wskaźniki BMI. Siła zaciskowa lewej ręki i siła rozciagania tułowia u mężczyzn, wytrzymałość i siła wykopu u kobiet w znacznym stopniu pokrywały się ze wskaźnikami klasyfikacji BMI. Możemy zatem wnioskować, że masa ciała nie wpływa na ogólną mobilność.

Wnioski. Niniejsze badanie potwierdzają wyniki naszych wcześniejszych badań, co może sugerować, że potrzebne są większe wysiłki na rzecz poprawy promocji zdrowia młodzieży w szkolnictwie wyższym. Wprowadzenie obowiązkowych zajęć wychowania fizycznego mogłoby pomóc w dalszych badaniach, które z kolei mogą prześledzić zmiany w stanie umiejętności sprawnościowych młodych ludzi.

Słowa kluczowe: sprawność fizyczna, wytrzymałość, studenci, aktywność fizyczna, umiejętności motoryczne

Ács P, Melczer C, Sávolt-Szabó T, Welker Z, Gyúró M, Baumann P, et al. Overview of the fitness parameters in the students of Pécs University. Health Problems of Civilization. 2017; 11(3): 150-157. doi: 10.5114/hpc.2017.70005.

Address for correspondence / Adres korespondencyjny: Pongrác Ács, Institute of Physiotherapy and Sport Science, H-7623 Pécs, Rét St. 4, Hungary, e-mail pongrac.acs@etk.pte.hu

Copyright: (C) 2017 Pope John Paul II State School of Higher Education in Biała Podlaska, Pongrác Ács, Csaba Melczer, Tünde Sávolt-Szabó, Zsanett Welker, Monika Gyúró, Petra Baumann, Kata Sey-Morvay, Bence Raposa. This is an Open Access journal, all articles are distributed under the terms of the Creative Commons Attribution-NonCommercial-ShareAlike 4.0 International (CC BY-NC-SA 4.0) License (http://creativecommons.org/licenses/by-nc-sa/4.0/), allowing third parties to copy and redistribute the material in any medium or format and to remix, transform, and build upon the material, provided the original work is properly cited and states its license. 


\section{Background}

Fitness status of any population is greatly determined by its individuals' behaviours. Healthy lifestyle involving physical activity, which is associated with outstanding stamina, is an essential factor in the success of the growing generation. Effects of physical activity and benefits of regular exercising have been examined in several national and international studies $[1,2,3,4]$. Sedentary lifestyle and increasing obesity are typical not only of youth but of the whole society [5]. Besides, health behaviour of young adults abounds in poor eating habits and lack of regular and quality sports activities. It should also be mentioned that obesity is more and more visible in childhood, which is becoming a risk factor in older generations $[6,7,8,9,10,11]$. A survey in Texas examined the fitness level of 1010 elementary and high school students. According to the conducted anthropometric measurements, every third child was classified as obese [11].

Further, international research shows that the findings of school anthropometric and fitness tests correlate with the students' physical activities $[12,13,6]$. These findings greatly affect adults' fitness level, i.e. there is a strong correlation between stamina in childhood and adulthood $[9,10]$.

Childhood obesity is said to be a public health problem in Hungary as well; therefore, state interventions should popularize regular exercise and regard it as a priority. Above all, it should be emphasized that one can find pleasure in everyday physical activity but students' motivation and interests should be taken into account. Educational institutions in Hungary have been measuring fitness indicators for a decade now. Measurement and evaluation of motor skills in students have always been a priority in public education. In order to facilitate the process, the National Integrated Student Fitness Test (NETFIT), a health-centred and criterion-oriented test, was developed by the Hungarian Student Sports Association in cooperation with the Cooper Institute. It has been applied as a fitness measurement test in Hungarian schools since the academic year 2014/15 [14].

According to the former, international surveys examining young adults $[12,15,16,17,18]$, numerous students in higher education struggle with excessive weight, which affects the results of their motor skills (shuttle run, powered long-jump) unfavourably [19,20,21], despite the fact that a survey from 2008 showed no correlation between obesity and flexibility [15]. During their university years, students' health behaviour deteriorates, which is associated mainly with weight gain $[16,18]$. Wetter et al. [18] carried out a long-term (a five-year) study in students in higher education. Having conducted the test, they came to the conclusion that young people's health indicators, i.e. body weight, BMI, BP and stamina, deteriorated significantly within the period.

A comprehensive test evaluating the fitness status has not been applied in young Hungarian adults yet. Thus, in the present study we wish to examine the stamina of students in higher education, because young people's health behaviour, fitness status, and nutrition habits, as indicated in the previous research, are below of the recommended values. The following survey bases on the students of Pécs University's results, in which their motor skills were examined by the NETFIT fitness assessment test. The objective of the study was to present a comprehensive view on young people's fitness status and BMI.

\section{Material and methods}

The survey was conducted several times in the year 2015, during which sample groups were examined. The participants were recruited from the students of Pécs University and altogether comprised 278 persons. When broken by gender, the survey group predominantly consisted of men $(79.13 \%)$, whereas women amounted to $21.87 \%$ of its population.

The students were tested in six NETFIT motor skills tests: (1) a 15/20-minute-long shuttle run, (2) abdominal muscle test (3) manual clamping force measurement (4) a push up test (5) a standing long-jump test, and (6) a flexibility test. The persons' motor fitness level was assessed with a motor test. A view on one's nutrition status was received in anthropometric examinations. The BMI was calculated on ones' body height and weight. In addition, body fat percentage as well as muscle and visceral fat mass were also measured.

The data were processed by IBM SPSS 21.0 statistical software. For the comparative analysis of the variables, a variance analysis (ANOVA) was applied. The significance level assumed in the study was $\mathrm{p}<0.05$ with $95 \%$ confidence interval.

\section{Results}

As for the achieved results from anthropometric measurements, it turned out that they were heterogeneous in both sexes. The data of the participants mainly concerned their body weight and height. On calculating the BMI, it was found that $68 \%$ of the men and $66.5 \%$ of the women were classified as normal. $23 \%$ of the men and $28 \%$ of the women were classified as obese (Figure 1). 


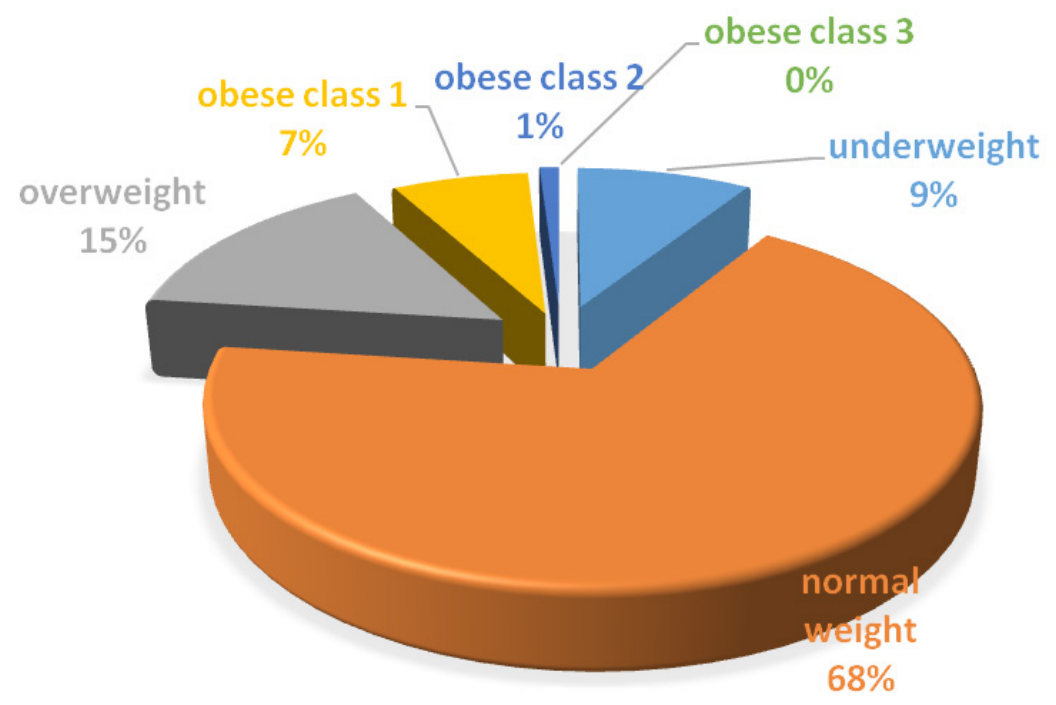

Figure 1. The participants' BMI categories (male) $\mathrm{N}=57$

The body composition was assessed by measuring visceral fat surrounding the essential organs located in the abdomen. In the light of the achieved results regarding the visceral body fat, it was concluded that the status of both sexes was positive as there were few persons in high risk category in the sample group (normal range:1-9\%; higher risk range: above $9 \%$ in both sexes).

As for body fat percentage, the sample results were again heterogeneous. The measured differences were due to the sex differences in most of the cases and to the increased fat mass in some cases. The latter case was evidenced in those with excessive weight in BMI (two men, four obese women with extreme values). Then, skeletal muscles were measured, which usually amount to $40 \%$ of the body weight and $50 \%$ in athletes. Skeletal muscle percentage in men varied between 15.4 and $49.1 \%$ with the mean of $37.67 \%$. This indicator for women was $28.31 \%$..

Next, basal metabolism (at rest) was measured with a bioimpedance device. Basal metabolism ranged between 1388 and $1947 \mathrm{kcal}$ in men, mean 1792kcal. The measured metabolism in women ranged between 1153 and $1825 \mathrm{kcal}$. In all, the mean metabolism for women stood at $1375 \mathrm{kcal}$.

The fitness status based on all physical fitness measures included in the motor test, which was performed according to NETFIT regulations.

As for manual clamping force test, both limbs were measured separately. On comparing the measured values in both hands, the clamping force of the right hand was stronger in both sexes with a slight difference visible. The average of the right manual clamping force in men was $48.33 \mathrm{~kg}$ (left hand: $46.1 \mathrm{~kg}$ ). The average of the right manual clamping force in women was $31.6 \mathrm{~kg}$ (left hand: $29.2 \mathrm{~kg}$ ) (Figure 2).

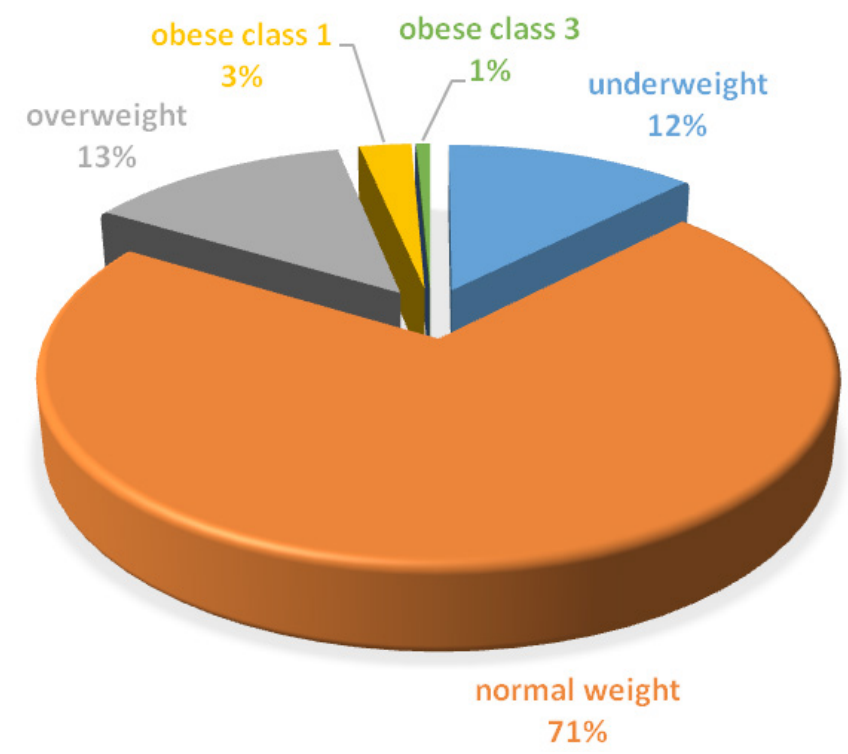

Figure 2. The participants' BMI categories (female) N=221 
Trunk muscles strength was measured by two tests: First, a scheduled ABS test was applied to measure ABS strength. Then, the distance between the tubercle and the ground during a single strain lift to measure trunk muscles strength was calculated (Figure 3).

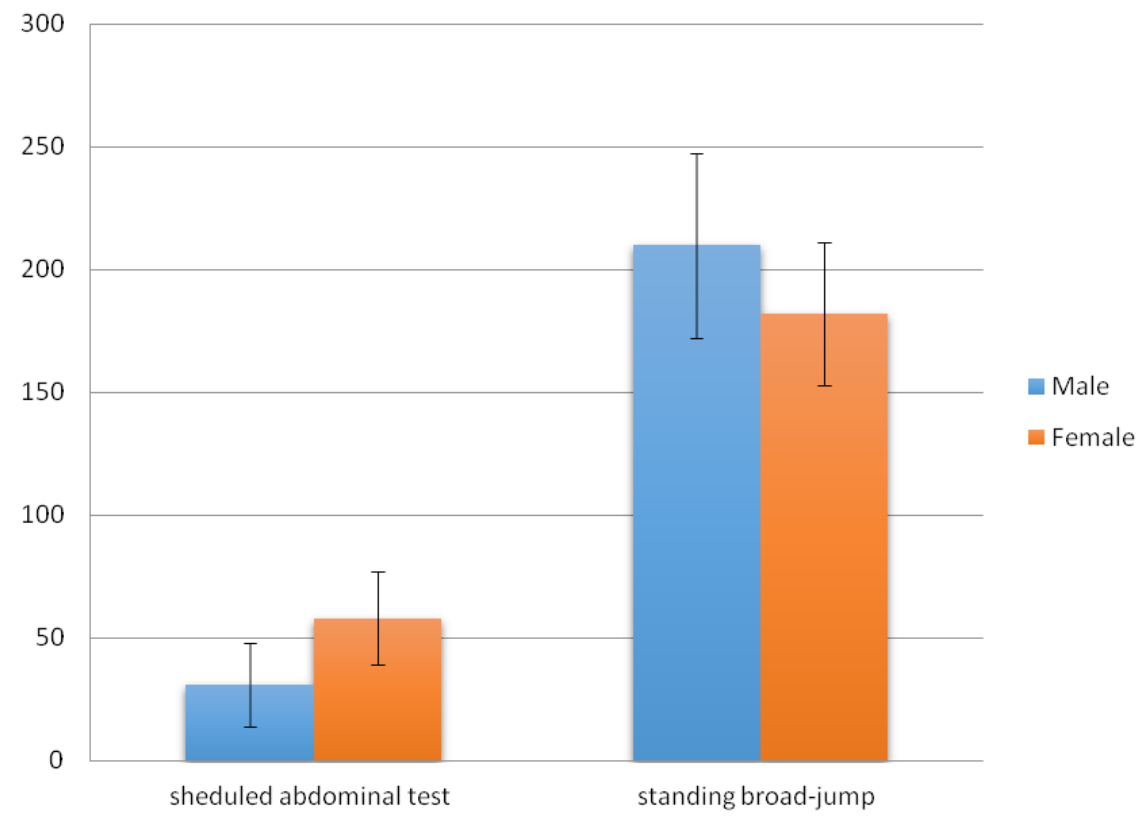

Figure 3. Sheduled abdominal test (rep. numb.) and standing long jump (cm) means

The explosive strength of the legs was tested in the standing long-jump exercise. Men achieved $209.7 \mathrm{~cm}$ on average. The average value for women was $182 \mathrm{~cm}$.

Similarly to ABS test, the test measuring shoulder strength was carried out as a push-up exercise with a scheduled NETFIT soundtrack. 20-45 repetitions were measured in men, and 8-28 in women. This difference was manifested in the average counts. In case of men, the mean number of repetitions amounted to 31 , whereas for women - 16.8 (Figure 4).

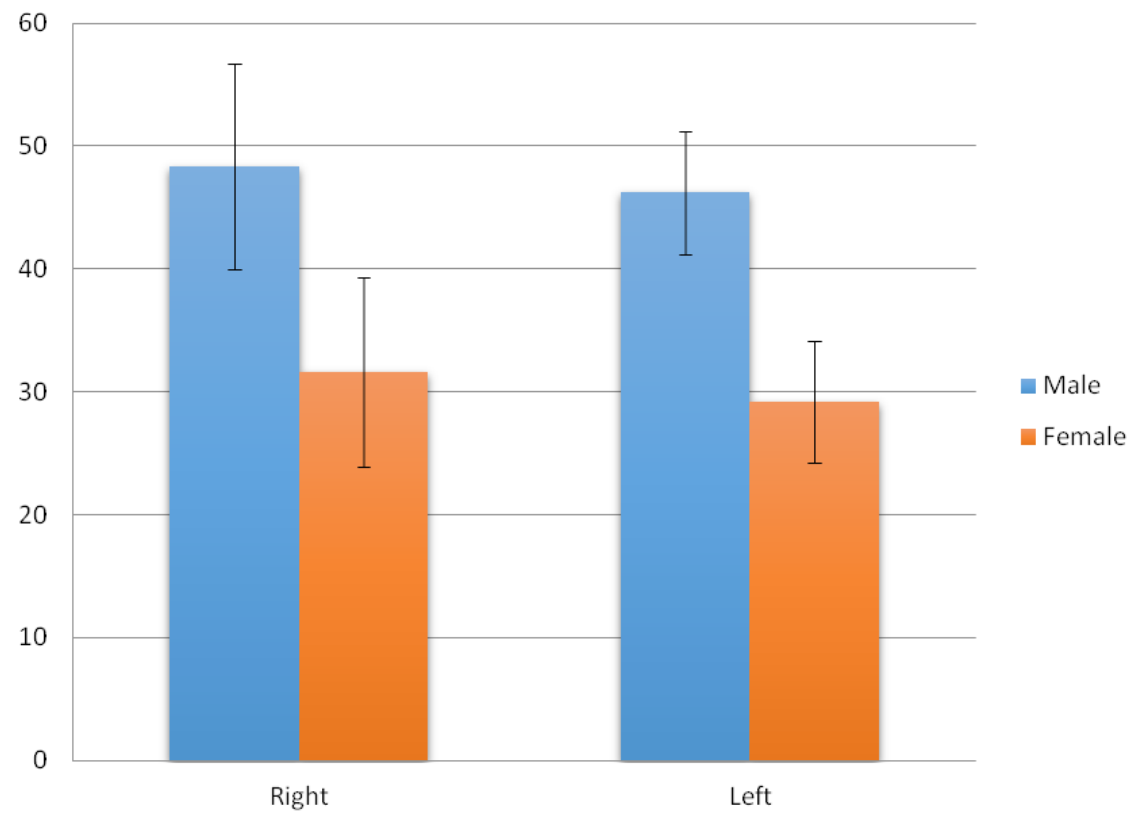

Figure 4. Manual clamping force means (hands' max. clamping strength)(kg)

The next test was hip joint examination which was to determine flexibility on both sides. The average value in right side flexibility was $32 \mathrm{~cm}$ for men, and $38.2 \mathrm{~cm}$ for women (Figure 5). 


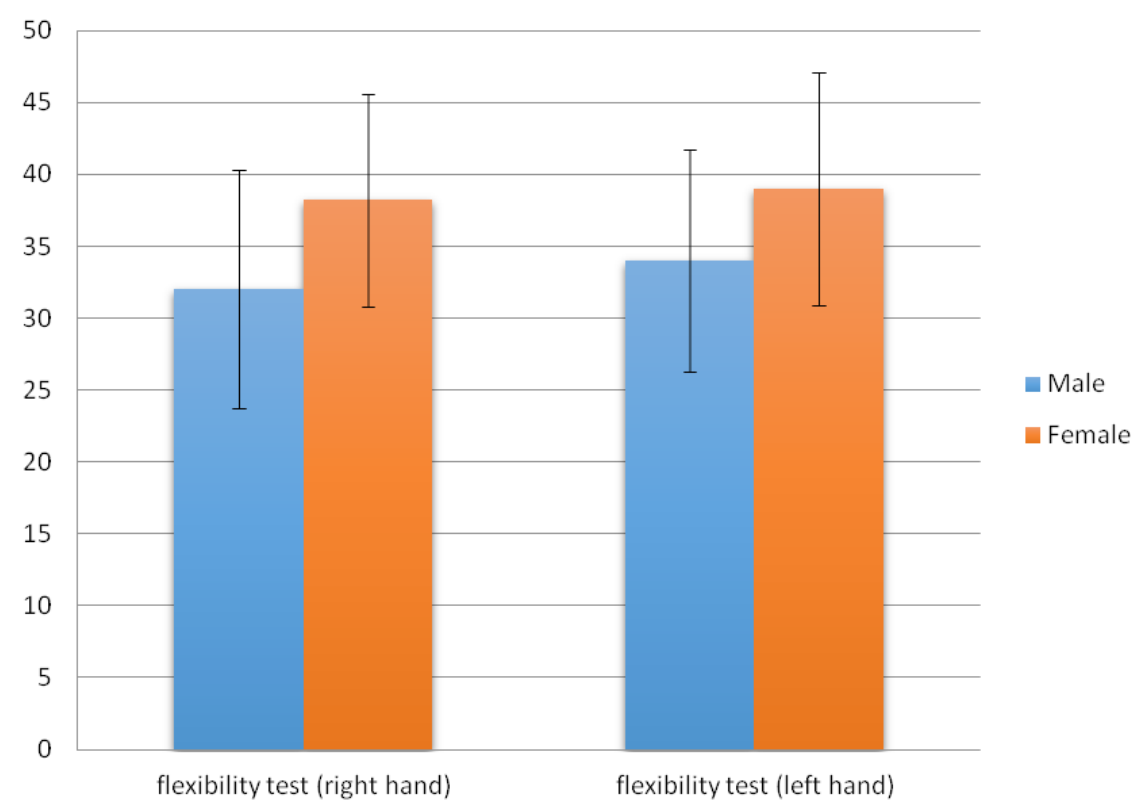

Figure 5. Flexibility test means (extensibility and mobility of flexing muscles )(cm)

The aerobic fitness profile was determined by the agility shuttle run. Participants had to run back and forth between two marked lines over a 20-metre distance. The survey measured the number of repetitions of the full distances. The number of full distances in men ranged from 49 to78; therefore the average in the sample group stood at 62.3. Fewer full distanced were evidenced in women as they ranged between 22 and 39 . The average of repetitions in the female group amounted to 34.5 (Figure 6).

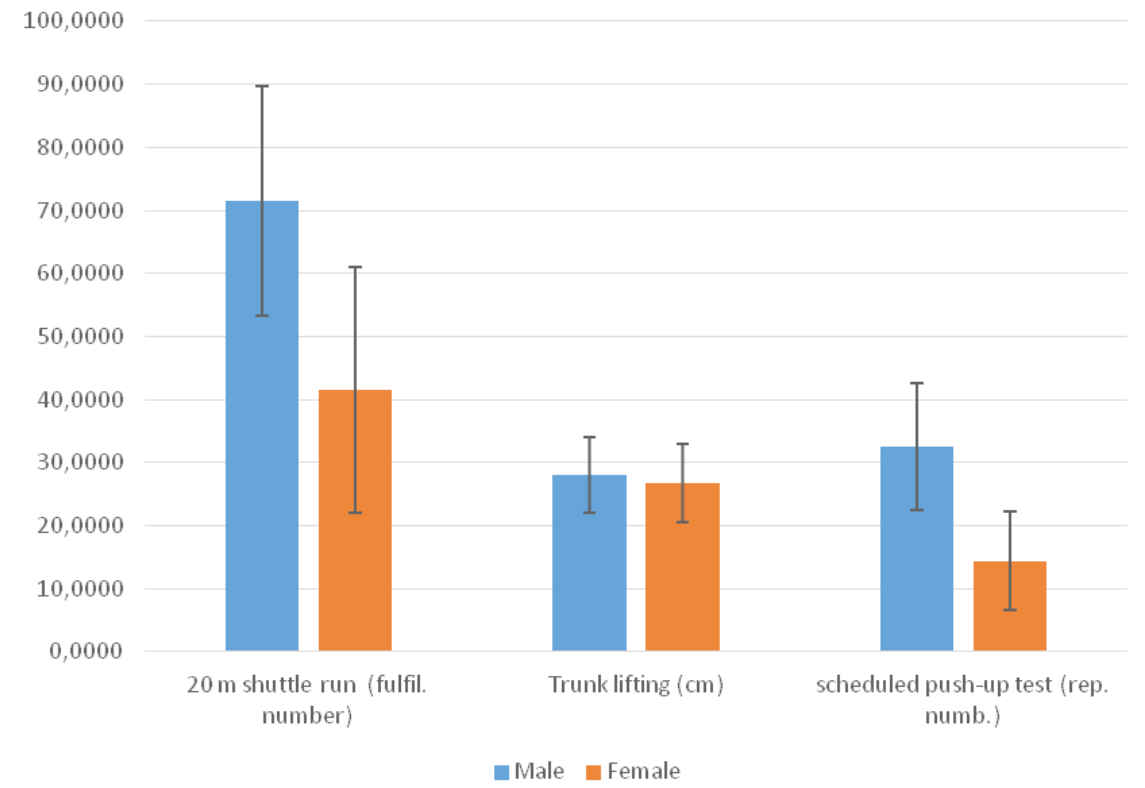

Figure 6. Other (fitness parameter) test means

Next, fitness parameters were compared to the those specified by the BMI categories. Significant differences were found in several cases, but some of them showed significant correlations between BMI and fitness tests. In case of men, the body weight affected the left manual clamping force $(\mathrm{p}<0.29)$ and the push-up test $(\mathrm{p}<0.09)$ significantly. As for women's results, a significant correlation was found in two tests. The BMI determined standing long-jump $(\mathrm{p}<0.00)$ and 20 -meter shuttle run $(\mathrm{p}<0.17)$ in women. Finally, the findings of the joint flexibility do not indicate any significant relationship between one's BMI and flexibility in either of the sexes. 


\section{Conclusion, discussion}

The present study aimed to show the fitness and nutrition habits in the students at Pécs University in order to achieve a comprehensive view of health behaviour and motor skills in young adults.

The obtained findings on the nutrition habits are supported by several, previously done studies. Basing on the BMI categorization, one third of the study group's participants were found to be overweight or obese. Presently, as indicated by national and international data, childhood obesity spreads like an epidemic. It also seems to be becoming an increasing risk factor for adults as they age [5,6,7,8]. 15.3\% of the non-athletic boys are overweight already at the age of 9 , and this number doubles by the age of 15 (31\%). As for girls, the rate of obesity amounts to $21 \%$ at the age of 10 . Accordingly, more than half of them can be considered as overweight (53\%) at the age of 15 [22]. San Miguel [11] examined 1010 elementary and high school students and his results showed that one third of the participants were classified as overweight or obese.

Similar results to the ones obtained at Pécs University are seen in international research concerning the nutrition habits of young adults [9,21]. For example, the nutrition habits and fitness status of 162 adults in higher education were examined in Lincoln, 2012. 31\% of the participants were classified as overweight [21]. Another two American research outcomes presented an even more worrying results in smaller groups. Out of 36 students in higher education, 19 persons' BMI exceeded the normal indicators [19]. Another study, assessing 18-year-old females, found that more than half of the sample group $(n=61)$ were overweight (32 persons) basing on the anthropometric tests and BMI categorization [22].

Several studies indicated a correlation between one's performance and their silhouette in the conducted fitness tests. Fogelholm [15] compared the fitness results of 15/16-year-old students $(n=2266)$ to their body weight. Similarly to our results, a negative correlation was found between stamina, explosive strength and body weight. At the same time, the findings into joint flexibility and body weight did not show any significant correlation. A two-year-long longitudinal study carried out in the years 2006-2008 examined the correlation between stamina and overweight in young people. Aerobic endurance was measured in the shuttle run. The assessment of overweight was made the BMI calculator. The follow-up study found significant correlation between low aerobic fitness test results in the shuttle run and disproportionate weight gain [23].

Artero et al. [12] carried out fitness tests in several groups of adolescents between the ages of 13-18 years. In their examination, not only overweight but malnutrition were taken into account. It turned out that overweight affected some fitness tests in a negative way (shuttle run, standing long-jump, hanging with bent arms), but another trial (manual clamping force) was affected in a positive way. On the other hand, malnourished persons performed better in hanging with bent arms, but their manual clamping force was worse than that of persons who had normal weight or were overweight.

There was also an American study involving 772 college students, which assessed stamina, muscle force, and flexibility (ABS, push-up tests, sit and reach trial). The outcome of the research showed a negative correlation between stamina $(\mathrm{p}<0.00), B M I$, and flexibility $(\mathrm{p}<0.01)$. Further, there was no significant correlation between ABS, push-up tests, and BMI [9].

Finally, it must be stressed that young adults often encounter changes in their lives and tasks associated with stress, which often result from new challenges (relocation, new community, changed social role). Several studies reported that young people are affected by chronic stress effects following the high school period [24]. People tend to reduce their stress by unhealthy habits and improper nutrition. Besides, they pay less attention to healthy lifestyle, which could significantly affect their future life. Our study focused on a critical age group because college students' lifestyle can be characterized by reduced health protection and increased health harming behaviours. Being aware of these facts, we hope that this age group is also going to raise their health awareness concerning fitness.

Both national and international studies suggest that further efforts associated with health promotion in higher education are needed. The introduction of such measurements might be a solution that could influence young people's health behaviour. For example, compulsory physical education classes in higher education in which students would need to meet the demands in at least one sports course in order to get a diploma would represent a significant step forward. Finally, it must be said that longitudinal studies need further research in which the changes in young adults' fitness could be measured. An introduction of compulsory physical education courses would facilitate such research.

\section{Disclosure and acknowledgements}

This work/article was supported by the GINOP 2.3.2-15-2016-00047 grant. 


\section{References:}

1. Eurobarometer. Sport and Physical Acivity. [Internet] 2010. [cited 2017 Feb 26]. Available from: http:// ec.europa.eu/public_opinion/archives/ebs/ebs_334_fact_hu_en.pdf.

2. Felderer B, Helmenstein C, Kleissner A, Moser B, Schindler J, Treitler R. Sport und Ökonomie in Europe. Wien: SpeA; 2006.

3. Takács J. Rendszeres fizikai aktivitás és mentális egészség. A testmozgás szerepe a depresszió megelőzésében és kezelésében. Psychiatria Hungarica, 2014. (29. évf.) 4: 386-397 (in Hungarian).

4. Weiss MR. Motivating kids in physical activity. Washington: President's Council on physical fitness and sports [Internet]; 2000. [cited 2017 Feb 26]. Available from: http://files.eric.ed.gov/fulltext/ED470695.pdf.

5. Antal M, Péter S, Biró L, Nagy K, Regöly-Mérei A, Arató G, et al. Prevalence of Underweight, Overweight and Obesity on the Basis of Body Mass Index and Body Fat Percentage in Hungarian Schoolchildren: Representative Survey in Metropolitan Elementary Schools (National Institute for Food and Nutrition Science, Budapest, Hungary). Ann Nutr Metab. 2009; 54(3): 171-6. doi: 10.1159/000217813

6. Freedman DS, Khan LK, Serdula MK, Dietz WH, Srinivasan SR, Berenson GS. The relation of childhood BMI to adult adiposity: The Bogalusa Heart Study. Pediatrics. 2005; 115: 22-27.

7. Fryar DC, Carroll DM, Ogden LC. Prevalence of Obesity Among Children and Adolescents: United States, Trends 1963-1965 Through 2009- 2010, Division of Health and Nutrition Examination Surveys; 2012.

8. Han JC, Lawlor DA, Kimm SY. Childhood obesity - 2010: Progress and Challenges, Lancet. 2010 May 15 ; 375(9727): 1737-1748.

9. Lefevre J, Philippaerts MR, Delvaux K, Thomis M, Vanreusel B, Eynde BV, et al. Daily physical activity and physical fitness from adolescence to adulthood: A longitudinal study. Am J Hum Biol. 2000 Jul; 12(4): 487497.

10. Mikkelsson L, Kaprio J, Kautiainen H, Kujala U, Mikkelsson M, Nupponen H. School fitness test as predictors of adult-health related fitness. Am J Hum Biol. 2006 May-Jun; 18(3): 342-9.

11. San Miguel K. Reliability and Validity of the Fitnessgram® Physical Activity Items, Thesis prepared for degree of master of Science. University of North Texas, [Internet]. 2011. [cited: 2017 Feb 2]. Available from: https://digital.library.unt.edu/ark:/67531/metadc84271/m2/1/high_res_d/thesis.pdf.

12. Artero EG, Espana-Romero V, Ortega FB, Jiménez-Pavón D, Ruiz JR, Vicente-Rodríguez G, et al. Health-related fitness in adolescents: underweight, and not only overweight, as an influencing factor. The AVENA study. Scand J Med Sci Sports. 2010; 20(3): 418-427.

13. Baquet G, Twisk JW, Kemper HC, Van Praagh E, Berthoin S. Longitudinal follow-up of fitness during childhood: interaction with physical activity. Am J Hum Biol. 2006 Jan;18(1): 51-8.

14. Csányi T, Kaj M, Vass Z, Boronyai Z, Király A, Király PF. A magyar 10-18 éves tanulók egészségközpontú fizikai fittségi állapota. Kutatási jelentés a Nemzeti Egységes Tanulói Fittségi Teszt (NETFIT®) 2014/2015. tanévi országos eredményeiről. Budapest: Magyar Diáksport Szövetség [Internet]. 2015. [cited 2017 Feb 24]. Available from: http://www.mdsz.hu/wp-content/uploads/2014/10/NETFIT_2014_2015_ Eredm\%C3\%A9nyek_kivonat.pdf (in Hungarian).

15. Fogelholm M, Stigman S, Huisman T, Metsämuuronen J. Physical fitness in adolescents with normal weight and overweight. Scand J Med Sci Sports. 2008 Apr; 18(2): 162-70.

16. Gropper SS, Simmons KP, Connell LJ Ulrich PV. Changes in body weight, composition, and shape: a 4-year study of college students. Appl Physiol Nutr Metab. 2012 Dec; 37(6): 1118-23.

17. Serd GJ. Relationship between dietary intake, fitness level and body compositon in college-aged students, presented to the Faculty of The Graduate College at the University of Nebraska In Partial Fulfillment of Requirements For the Degree of Master of Science, [Internet]. 2012. [cited 2017 Feb 24]. Available from: http://digitalcommons.unl.edu/cgi/viewcontent.cgi?article=1148\&context=cehsdiss.

18. Wetter AC, Wetter TJ, Schoonaert KJ. Fitness and health in college students: changes across 15 years of assessment, Journal of Exercise Physiology Online. 2013; 16(5): 1-9.

19. Baghurst T, Richard K, Boolani A. Objective Measures of PETE Student Achievement and Maintenance of Physical Activity and Fitness (Oklahoma State University Stillwater USA). PHEnex Journal [Internet]. 2016; 8(1): 1-13. [cited 2017 Feb 24]. Available from: http://ojs.acadiau.ca/index.php/phenex/article/view/1623.

20. McGavock M, Torrance BD, McGuire KA, Wozny PD, Lewanczuk RZ. Cardiorespiratory fitness and the risk of overweight in youth: the Health Hearts Longitudinal Study of Cardiometabolic Health. Obesity. 2009; 17(9): 1802-1907.

21. Kovács V. Rendszeres testedzés szerepe a gyermekkori elhízás megelőzésében és kezelésében (Doktori értekezés. Semmelweiss Egyetem, Nevelés- és Sporttudományi Doktori Iskola) [Internet]. 2009. [cited 2017 
Feb 24]. Available from: http://phd.semmelweis.hu/mwp/phd_live/vedes/export/kovacsviktoriaanna.d.pdf. 22. James KJ. Assessing Dietary Intake, Eating and Exercise Attitudes and Fitness Levels in College-Aged Students. University of Nebraska in Lincoln, Nutrition and Health Sciences Dissertations and Thesis, [Internet]. 2010. [cited 2017 Feb 24]. Available from: http://digitalcommons.unl.edu/cgi/viewcontent. cgi?article $=1006 \&$ context $=$ nutritiondiss.

23. Price AA, Melicia C, Whitt-Glover MC, Kraus CL, McKenzie MJ. Body Composition, Fitness Status, and Health Behaviors Upon Entering College: An Examination of Female College Students From Diverse Populations. Clin Med Insights Womens Health. 2016; 9(Suppl 1); 23-29.

24. Bray SR, Kwan MY. Physical activity is associated with better health and psychological well-being during transition to university life. J Am Coll Health. 2006; 55(2): 77-82. 